\title{
School Library Utilization Technology Model to Improve Reading Interest and Reading Ability in Elementary Education
}

\author{
Arini Pakistyaningsih",*, Nurdyansyah², Moch. Bahak Udin By Arifin², Hendra Erik Rudyanto3 \\ Pandi Rais ${ }^{4}$
}

\author{
${ }^{1}$ Program of Educational Technology, Universitas Negeri Surabaya, Indonesia \\ ${ }^{2}$ Faculty of Islamic Studies, Universitas Muhammadiyah Sidoarjo, Indonesia \\ ${ }^{3}$ Faculty of Teacher Training and Education, Universitas PGRI Madiun, Indonesia \\ ${ }^{4}$ Faculty of Syariah, Institut Agama Islam Negeri Kediri, Indonesia
}

Copyright $@ 2019$ by authors, all rights reserved. Authors agree that this article remains permanently open access under the terms of the Creative Commons Attribution License 4.0 International License

\begin{abstract}
This study aims to determine the feasibility of the utilization model in school to increase students' reading interest and measure the effectiveness of the school library utilization model. This study uses a research and development approach by the theory of Borg and Gall. The research subjects were Library in Bubutan IV Elementary School Surabaya, Indonesia, with the research respondents being all students. The results showed that the library utilization model was very effective in increasing students' reading interest and reading ability. The results of measuring the Reading Text Level (RTL) of students showed that out of a total of 872 students, there were only $3.1 \%$ of students whose RTL level was still below the minimum standard. Thus, the model of school library utilization is significantly able to increase students' reading interest and reading ability. We recommended that the results of this study provide benefits for the practitioner to improve synergy in all relevant agencies to increase students' reading interest and reading ability since elementary level.
\end{abstract}

Keywords Technology Model, School Library, Reading Text Level

\section{Introduction}

Reading seems to have not been be considered as a prominent thing in Indonesia, although various efforts have been made to develop a reading habit. In Law Number 20 of 2003 concerning the National Education System, Chapter III Article 4 paragraph 5 states that one way of administering education is to develop a culture of reading, writing, and counting for all citizens [1]. However, the formal education curriculum does not support the formation of a reading habit.

Various facts about reading interest show that the reading habit of the people in Indonesia can be said to be very minimum. Data from the Central Statistics Agency (BPS) in 2012 [2], as many as 91.58 percent of Indonesia's population aged ten years and more prefer to watch television, and only about 17.58 percent of the population like to read books, newspapers, or magazines. In 2015, public reading interest showed 25.1 percent, there was an increase of 7.51 percent compared to 2012, but it was still in the low category.

The reading interest of the Indonesian people is still far behind compared to that of countries in Asia. The 2008 BPS data in his study explained that reading culture indicators in a country can be seen from the number of pages read per day, the results showed Singapore 116 pages/day, Malaysia 109 pages per day, Japan 150 pages/day, Korea 147 pages/days, compared with Indonesia which is only 0.9 pages/day. Apart from the number of pages that people read per day, the other indicator is to see a large number of books published, which shows Malaysia 15,000 titles/year, Vietnam 45,000 titles/year, compared to Indonesia which published only 8,000 titles/year. (BPS, 2008)

The results of the 2017 National Library research also show that the average Indonesian person only reads books 3-4 times per week, with an average duration of reading time per day of 30-59 minutes, while the number of books completed per year on average is only 5-9 books. The results of the study also showed that the level of interest or interest in reading in Indonesian society was only 36.48 percent or relatively low, although there was an increase compared to 2015 of 25.1 percent. By the Program for International Student Assessment (PISA) ranking 
conducted by the OECD, Indonesia is still ranked 69th out of 76 countries [3].

Another fact regarding the low reading interest in Indonesia can be seen from illiteracy rates that are still high, although there is a decline in each year. Based on the BPS report in 2018, literacy rates, which are the opposite of illiteracy rates, have increased every year. In 2010, the literacy rate in Indonesia was 92.44 percent. Four years later, literacy rates increased to 95.12 percent, and four years later, in 2018, the literacy rate became 97.93 percent (BPS, 2018). This shows that in 2018, the illiteracy rate in Indonesia is only around 2.07 percent, or there are still around 3.47 million people who are still illiterate (BPS, 2018). Illiteracy rates of 15-59 years old in Indonesia are seen from each province, there are still 11 provinces that have illiteracy rates above the national figure, the eleven provinces are Papua at $25.843 \%$, NTB $7.787 \%$, NTT 5.365\%, West Sulawesi 4.36\%, West Kalimantan 4.283\%, South Sulawesi 4.686\%, Bali 2.908\%, East Java 3.427\%, North Kalimantan 2.562\%. Then Southeast Sulawesi was $2.510 \%$, and Central Java was 2.267\% (BPS, 2018).

East Java Province is known to be one of the 11 provinces with illiteracy rates above the national rate, which is 3.427 percent. The most important effort in resolving illiteracy is to increase the awareness of the whole family that reading must begin with the family. The government's efforts through the Ministry of Education and Culture are providing literacy education program services and the development of a public reading culture, through basic literacy education programs and advanced literacy education, as stipulated in Permendikbud Number 86 of 2014 and Permendikbud Number 42 of 2015.

The low interest in reading in children is caused by three things, first because of the increasing number of types of entertainment, TV shows, recreational places, and even children's games that are decreasing children's time to read, reading is less popular than the activities of modern society [4], [5]. Second, because parents are increasingly unconcerned about their learning habits and children's reading habits; parents are increasingly busy with their affairs, so they forget to guide children to read anything. Third, there is no means and access to reading books, and the school library is still not well managed, so students have difficulty getting comfortable reading places.

Low reading interest enormously affects the quality of a nation, because with low reading interest the community cannot know and follow the development of information and science in the world, which in turn will have an impact on the nation's underdevelopment. The low interest in reading is also a potential threat to disrupt the program to improve the quality of human resources in all fields and layers of society because it can blunt sensitivity to many things, especially those related to humanity.

Nugroho [6] in his study explained the low reading interest of the Indonesian people is due to leisure and book prices. The Indonesian people's spare time is more available to work, so there is no time prepared for reading, even though reading is an activity that requires enough free time. A low reading habit can also be caused by motivation, economy, habits, culture, technological developments, and lack of reading services.

Schools are formal education facilities that play a major role in the development of reading literacy and the development of reading culture for the community from an early age so that it is expected to contribute to the intellectual life of the nation. The government has this responsibility, starting from the centre to the regional level, as mandated by the constitution that the state is obliged to educate the life of the nation (the fourth paragraph of the Preamble of the 1945 Constitution). The state's obligation to increase reading interest is also regulated in Law Number 43 of 2007 concerning the Library [7]. As a form of implementation, the government continues to develop the world of education, one of which is by increasing reading interest through the massive literacy movement and the development of the Community Reading Park (TBM) model. TBM is built on this matter by the Ministry of National Education to accelerate the literacy movement and reading culture that can reach all levels of society.

The public's reading interest in the city of Surabaya is still low and needs to be improved. From the results of research conducted in Surabaya by the Independent Team in 2010, community reading interest in Surabaya was only $26 \%$, then in 2011 research was conducted again with a wider sampling of results of only $28 \%$ (including low categories), with service interventions establishing hundreds of libraries and TBM and the revitalization of school libraries, both physical and work programs starting from 2007 until now, the research was carried out again and the results had increased to $59.6 \%$ (medium category).

The ideal condition of library management, according to the Indonesian National Standard (SNI) Number 7329 of 2009 concerning School Libraries, is that the school library aims to provide a learning resource center so that it can help the development and improvement of interest and reading abilities, talents and abilities of students.

School libraries have very important goals, but now the function to achieve these goals is not in line with their realization. Most students visit the school library only to borrow books because of the assignments given by the teacher at rest, the students' interest in visiting and reading in the library is very low. Most school libraries also do not work in accordance with the function and purpose of the library because the school library does not have librarians, but their teachers maintain the library. Sometimes libraries are left alone; no one keeps them, and it makes school students confused and do not understand if he wants to enter and read books; this has an impact on students' low reading interest. Such conditions are not in accordance with the School Library Standards according to SNI Number 7329 of 2009, which states that human resources in the school library must consist of at least three people, 
including the head of the library, library staff (librarians), and people who are in charge of developing library human resources.

Another disadvantage is that most school teachers are less creative to make spatial planning or make libraries more attractive, less able to give an understanding of libraries that actually libraries are not only used for reading books but libraries are places to get information, so students become bored and only understanding a library is a place/building in which there are books. The function of the library is more dominant as an administrative function, not an informative function, because according to SNI Number 7329 in 2009, the school library in addition to educational and administrative functions, must also function informally, namely the library provides library materials that contain information about various branches of quality science and up-to-date that are arranged regularly and systematically, so that it can facilitate the officers and users in finding information needed.

The school library system currently only serves until the last break, when school hours end and when students leave the class, students cannot be stopped by the library because the library has closed early, which makes library functions ineffective. It is also not by SNI No. 7329 of 2009 that the time given by the library to provide services for users is a minimum of eight hours a day.

The use of school libraries must also be supported by the quality of library managers, especially manners; this is in accordance with Republic of Indonesia Minister of Education and Culture Regulation number 23 of 2015 concerning the growth of character, which considers that every school should be a comfortable place and provide inspiration for students, teachers, and/or other education personnel; besides that, character education should be a joint movement involving the government, local government, society, and/or parents. With the development of character, it is expected that schools, especially libraries can be a fun learning park for students, and develop good habits as a form of character education in schools and develop a harmonious environment and reading culture between family, school, and society. The current condition, the quality of character of the management of the school library is still far from what is expected, which is indicated by the lack of innovation and even a little indifferent about how the strategy for developing the school library can increase students' interest and reading ability. Chettri [8] in his research on reading habit, discussed the importance of building character to increase reading interest.

Reading interest needs to be an important concern because it relates to reading literacy culture; low reading interest shows that reading literacy is still not a culture in a society. The literacy culture of reading is the key to the progress of a nation so that the ability to read and write is the main requirement for building a civilization in a country. The culture of reading literacy is also the key to science, so it is important to build quality education by building a reading culture.

Recently, the responsibility for increasing reading interest only runs partially for each school learning source institution, so that building a reading literacy culture runs slowly, unstructured, passive, and unsustainable. The responsibility for increasing interest and reading ability of students through school learning source institutions is relatively running on their own [9]-[11]. The novelty of this research is to develop a model of the use of school libraries as a comprehensive institution in the city of Surabaya which together builds Surabaya as a City of Literacy, with the hope that the future interest and reading ability of students in Surabaya can be built in a structured, massive, systemic and sustainable manner.

Previous research which discussed the model for increasing reading interest has been widely done, including Wigfield et al. [12] with the title "Intervening to Improve Children's Reading Motivation and Comprehension: Concept-Oriented Reading Instruction." This study aims to describe the development and implementation of comprehension reading instruction programs, called Concept-Oriented Reading Instruction (CORI). CORI is designed to increase students' motivation and reading comprehension. The CORI instructors at the school focused on five teaching practices to increase students' motivation for reading, namely: (1) providing thematic content goals; (2) optimizing choice; (3) hands-on activities connected to reading; (4) providing interesting texts; and (5) fostering collaboration. Wigfield et al. [12] also developed an engagement model to improve students' reading skills, which consisted of four components, namely, social interaction, conceptual knowledge, motivations, and strategy use.

Another study is conducted by Karim and Hasan [13] with the title "Reading habits and attitude in the digital age," regarding the importance of improving reading skills in the digital era. Rosaen's research [14] with the title "The potential of video to help literacy preservice teachers learn to teach social justice and develop responsive instruction" also explained the role of digital in fostering a literacy culture of reading.

The use of the school library utilization model in the city of Surabaya is currently not effective, because it is less proven in increasing students' interest and reading ability. The scope of this study relates to the problems that occur, namely the low interest and reading ability of students, especially elementary school students, both public and private in the city of Surabaya, which is due to the education unit not having an obvious work program in order to increase students' interest and reading ability. For this reason, we need a model for the use of school libraries to increase the learning interest of students in the city of Surabaya.

Based on the background mentioned above, through a strategy to foster a reading culture of school students in the city of Surabaya, it is expected that there will be an 
increase in reading interest to be higher in the coming years. Furthermore, a model for the utilization of the school library will be developed, so that good synergies arise in the implementation of programs and activities can foster students' interest and reading culture in the city of Surabaya. Thus, in this study, the researcher took the title "Development of utilizing School Libraries model to Increase the reading ability and reading interest of students in the City of Surabaya."

In general, this study aims to develop a model of school libraries utilization in order to increase reading interest and reading ability for school students, while specifically, this study aims to (1) know the appropriateness of school library utilization model to increase students' reading interest and reading ability in the city of Surabaya; (2) measuring the effectiveness of the school library utilization model to increase students' reading interest and reading ability in the city of Surabaya.

\section{Materials and Methods}

In this study, the design that will be used uses a Research and Development (R \& D) approach. Sugiyono [15]-[17] explains that the Research and Development method is a research method used to produce certain products and test the effectiveness of these products.

This study uses a model of research and development from Borg and Gall. In development research, according to Borg and Gall [18], the research design is needed. Borg and Gall state that the stages of research and development are carried out sequentially, and each stage always refers to the previous stages, until finally, a new development model is obtained.

Research variables and conceptual definitions are definitions of the variables used in this study, including:

1. Interest in reading

2. Reading ability

3. $\quad$ Reading Text Level (RTL)

4. Model of Utilizing School Libraries

5. Data Collection Instrument

Reading interest is a motivation that encourages people to carry out activities that can be developped by seeing and doing spelling that has meaning that can then make someone more developed and open to his insight. Student's interest in reading is measured by several indicators, namely (a) Happy feelings of students when reading; (b) The desire to read every day; (c) The desire to visit the library regularly; (d) Students' understanding of the book read; (e) Additional insights obtained after reading; and (f) Reading hobby brings benefit for students.

Reading ability is the ability to access, understand, and use things intelligently through various activities, including reading, seeing, listening, writing, and speaking. The reading ability of measurement can be divided into 12 indicators, namely (a) The ability to read quickly; (b)
Phonological awareness, namely the ability to read with understanding; (c) The ability to retell reading books; (d) Ability to summarize (resume); $€$ Articulate empathy for the character of the story; (f) Separating facts and fiction; (g) Presenting stories effectively; (h) Know the type of writing in the media and its purpose; (i) Ability to focus on understanding the content of reading; (j) The ability to understand the contents of the reading; $(\mathrm{k})$ The ability to retell the contents of stories with their own language and express opinions on the story; and (l) The ability to write responses to the storyline

Reading Text Level (RTL) is a reading assessment of students based on pronunciation, fluency, and understanding. Selection of words for assessment pays attention to vocabulary, illustrations, print, content, and concepts. The assessment category consists of level 1 to level 7. The concept of RTL measurement is based on cooperation between the Surabaya City Government, in this case, the Library and Archive Service with the Surabaya State Islamic University (UINSA) in the "Building Surabaya City Literacy" program.

The model of school utilization in this study will refer to SNI Number 7329 of 2009 concerning School Libraries, which includes (a) Collection; (b) Library material processing; (c) Library material maintenance; (d) Human Resources; (e) Library services; (f) Organizing a library; (g) Room; (h) Furniture and equipment; (i) Budget; (j) Information and communication technology; (k) Library collaboration; and (l) Library

In this study, the sample of the research object was Bubutan IV Surabaya Public Elementary School (SDN) Library, with speakers including (1) Principal; (2) Head of the Library; (3) Teacher; (4) Student library visitors (users)

The procedure for developing the library management model in this study uses the concept conveyed by Borg \& Gall in Sukmadinata [19], describing the 10 steps of the implementation of the research strategy and development of a model as follows: (1) Research and information collecting; (2) Planning; (3) Develop preliminary form of product; (4) Preliminary field testing; (5) Main product revision; (6) Main field testing; (7) Operational product revision; (8) Operational field testing; (9) Final product revision; and (10) Dissemination and implementation

The data collection instruments used in this study are as follows: (a) In-depth interviews; and (b) Measurement of reading ability using RTL using an Android-based application "Let's Read". Data analysis techniques in this study using mixed methods, namely: (1) Test Validity; (2) Reliability Test; (3) Descriptive statistics; and (4) Paired Sample T-Test.

\section{Results and Discussion}

\subsection{Description of the Use of the School Library}

The results of the preliminary study of school library 
management at Bubutan IV Surabaya Elementary School showed that overall the school library had been managed by SNI Number 7329 of 2009 concerning School Libraries. There are several aspects that are still not appropriate to the standard, and they are as follows: the number of fiction and non-fiction books is not balanced, library collections have not been systematically arranged, librarians have not received certification, librarians have never received library training, there are no educational services for library visitors, duration open libraries are still less than the standard 8 hours per day, the area of the collection is still less than the standard $45 \%$ of the total area, utilization of information technology has not been managed optimally, and there is no synergy of cooperation with libraries or other bodies.

Physical improvements such as expanding the collection area and rearranging collections to be more systematic can be done more easily. Non-physical improvements are also important, such as educational services for users. Sulistyo and Basuki [20] explained that the library must also have an educational function, namely as a non-formal and informal education facility, meaning that the library is also a place to study outside of school. The use of technology is also important; this is also confirmed by the statement of Sulistyo and Basuki [20] that libraries must function as information centers that help all teachers and students who need information, and information can be more quickly accessed with the help of information technology.

The results of the preliminary study also show that students' reading interest is still lack, as the reading interest indicator of students are still below average, students still feel less happy when they are in the library, and students have not gained additional insight after reading books in the library. This shows that students cannot read effectively so that students do not get insight after reading books in the library. Also, the conditions in the library are still too rigid and are considered to be less pleasant for students, according to the statement of Elkin et al. [21] that building reading skills must also go through the pleasure of reading, meaning that reading must be made with pleasant patterns.

The results of the preliminary study on students 'reading ability also showed that students' reading ability was still lacking, with the reading ability indicators of students who were still below average, students could not yet read along with a good understanding of the books being read. It also shows that students do not have good and correct reading skills, so students have difficulty understanding the books that have been read. In addition, the students' ability to articulate empathy with the characters is still lacking, the ability to know the type of writing in the media and its purpose is still low, the ability to understand the contents of the literature is still weak, the ability to retell the contents of the story with their language and express their opinions on the story is lacking, and the ability to write responses to the storyline is still lacking.

The results of student RTL measurements before the implementation of the library utilization model showed that out of a total of 872 students, there were 357 students or $41 \%$ of students whose RTL level was still below the minimum standard. This shows that there are still many students whose reading text level still does not meet the standard.

Information from the results of preliminary studies is needed by researchers as information to arrange treatments by developing a model of the use of school libraries, so that reading interest and students' reading ability can increase so that the RTL level can be met to its minimum level. The preparation of the school library utilization model comes from several materials, namely school management standards that refer to SNI Number 7329 of 2009 concerning School Libraries and 6S strategies (human resources, organizational structure, systems, infrastructure, strategies, and synergies).

\subsection{Strategies for Developing Models for Using the School Library}

The strategy for developing the school library utilization model will be prepared based on the theory of Borg and Gall, which consists of 10 stages, and can be grouped into four main stages, namely preliminary studies, planning, model development, and model validation.

The results of a preliminary study on the condition of school library management show that the management of school libraries is still not optimally managed, including collections, librarians, collection areas, information technology, and synergies. Therefore, treatment needs to be done to increase students' interest and reading ability through improving library management. Subandijah [22] explains libraries as one of the students' learning resources require good management and organisation so that learning resources are easily accessed and also used by interested parties. Warsito [23] added that libraries are learning resource institutions that must be managed and utilized properly to help increase effectiveness and efficiency in learning activities.

Furthermore, at the planning stage, a research plan is prepared, which will be technically carried out for six months, starting from the activities of preparing equipment, preparing human resources, to dissemination activities. The equipment needed consists of theoretical books related to reading interest, reading ability, and Reading Text Level (RTL) measurements, while the human resources needed are assessors, who are tasked with helping programs to use the school library while measuring interest in reading, reading ability, and RTL in students. Assessor in this study were 18 people.

In the development phase of the model, the first product $\mathrm{draft} /$ development will be developed, then the initial trial, 
model revision, broader field trials, and product refinement results from field tests. The draft product development was prepared by making improvements to the management of the school library by SNI Number 7329 of 2009 concerning School Libraries. Improvements include collections, library material processing, library material maintenance, human resources, library services, library management, space, furniture and equipment, budget, information, and communication technology, and library cooperation. Furthermore, the program is carried out referring to the $6 \mathrm{~S}$ program, including preparing human resources, arranging effective organizational structures, designing systems, preparing facilities and infrastructure, developing strategies, and building synergies. After the programs have been implemented, measurements are then taken on students, with students' reading interest instruments, student reading ability evaluation instruments, and Reading Text Level (RTL) measurement instruments.

The development of a library utilization model is compiled following a hybrid pattern, Mudhoffir [24] explains hybrid patterns are a combination of separate patterns and centralized patterns. This is because the school library at Bubutan IV Surabaya Elementary School has a building with a centralized organizational pattern, and the implementation of library programs aim to increase students' interest and reading ability, not all of them are done centrally in the library, but also other locations, namely working with each homeroom teacher to carry out library programs in each class.

After the initial draft of the library utilization model had been compiled, then an initial trial was carried out directly at the Bubutan IV Surabaya SDN School Library, to find out the obstacles that could be experienced. Improvements to the management of the school library based on SNI Number 7329 of 2009 were carried out with several aspects that were known to not abide by the standards, as well as the implementation of the 6S strategy in the school library utilization model, which was carried out with several programs previously described.

The results of the initial experiment showed that improvements in school library management did not have significant obstacles, both in management according to standards and in the implementation of the 6S strategy, both in fostering technical officers, library organizational structure, systems, infrastructure, strategies through compulsory reading activities, and synergy with Surabaya City Library Agency.

After conducting the initial experiment, the program was then tested to increase reading interest and to readability with a sample of student groups. The duration of the program is carried out for one week, by carrying out several programs, namely the compulsory reading curriculum, summarising the contents of the book, library friends, bitter stories, and speed reading. After testing the program, measurements of reading interest, reading ability, and RTL were then carried out.

After the trial in a limited group, the library utilization model was carried out thoroughly for all students from grade 1 to grade 6 . Implementation of library utilization programs was conducted for 3 months, starting from March to May 2018, and then evaluating whether the application of the book model of the use of the school library is able to increase reading interest and reading ability of students, and also increase the level of RTL of students according to the level at least every level of the class.

The evaluation results show that overall, the school library has been managed by SNI Number 7329 of 2009 concerning School Libraries. Some aspects that were previously not appropriate have been adjusted according to the standard. The proportion of fiction and non-fiction books becomes 1: 4.2 (minimum standard is 1: 4), library collections have been systematically compiled. Librarians have received certification from the City Library Agency, and librarians have also received library training. There have already been educational services for library visitors. The library's open duration is more than 8 hours per day. The collection area is more than $45 \%$ of the total space. information technology has been optimally managed, and there is already a synergy of cooperation with other libraries.

Furthermore, the evaluation results of students' reading interest and reading ability showed that the average score of students' reading interest was 3.84, an increase compared to the pre-test of 3.52. This provides information that conditions in the library have been improved, and students already have insight and skills on how to read well, so that students' reading interest is increased. The results of the measurement of students' reading ability also showed that the average score of students' reading ability was 3.73 , an increase compared to the pre-test of 3.48. This shows that students already have good and correct reading skills, so students easily understand the books that have been read. Furthermore, there is also an increase in the students' ability to articulate empathy with the characters, know the type of writing in the media and its purpose, understand the contents of the story, retell the contents of the story with their own language and express opinions on the story, and write responses to the storyline. While the results of student RTL level measurements after implementation showed that out of a total of 872 students, there were only 27 students or only $3.1 \%$ of students whose RTL level was still below the minimum standard. Far down compared to the pre-test, there were $40.1 \%$ of students whose RTL level was still below the minimum standard.

After a comprehensive implementation, the next step is to validate the expert. Evaluation activities are carried out in three stages, namely, design evaluation, content evaluation, and media evaluation. The results of the design evaluation of the use of the school library model 
produced a value of 89.3, which showed good evaluation results and did not need to be revised. The results of the evaluation of the design of the school library utilization model resulted in a value of 90.9, which showed good evaluation results and did not need to be revised. Finally, the results of media evaluation of the school library utilization model produced a value of 90.0, which also showed good evaluation results and did not need to be revised.

After validation, the next process is product dissemination, which is carried out to promote the product model of school library utilization to increase students' reading interest and reading ability. Product promotion is done so that users can accept it; in this case, the broader primary school library. Product dissemination or dissemination of the school library utilization model will be carried out in several institutions, namely the Surabaya City Library Agency and the Surabaya City Education Office [25], with the hope that later this model of school library utilization can be applied massively to elementary schools in Surabaya City.

\subsection{Effectiveness of the Model of Using the School Library}

The effect of the school library utilization model development can be seen by comparing students' reading skills before and after the model implementation. The results of effectiveness based on the conditions of school library management show that overall the school library has been managed by SNI Number 7329 of 2009 concerning School Libraries [26]. Some aspects that were previously not appropriate have received attention and improvement from the library manager. Furthermore, students' reading interest after implementation (post-test) shows a good average score, and this provides information that conditions in the library have been improved, and students already have insight and skills on how to read well, so that students' reading interest becomes increase. The reading ability results also increase, which shows that students already have good and correct reading skills, so students easily understand the books that have been read. There is an increase in students' ability to articulate empathy for the characters, know the type of writing in the media and purpose the contents of the reading, retell the contents of the story with their language and expressing opinions on the story, and students have been able to write responses to the storyline.

Comparative analysis of students' reading interest before and after the implementation of the school library utilization model shows that there is an increase in students' reading interest after the implementation of the book model of school library utilization, students are more amused, want to visit the library regularly, better understanding, and visits to the library can add insight for students [27]-[29]. A relatively small increase occurred in the desire to read and love to read. This could be an evaluation for the school library at Bubutan IV Surabaya Elementary School that the six-month repair period is still too short, so this activity needs to be carried out continuously so that students have more desire to read and love to read.

Furthermore, the comparative analysis of students' reading ability before and after the implementation of the school library utilization model shows that there is an increase in students' reading ability after the implementation of the school library utilization model, students have the ability to read with understanding, are able to retell better, and have better summarizing ability. A relatively small increase occurs in speed reading skills. This can also be an evaluation of the school library at Bubutan IV Surabaya elementary school that this activity needs to be carried out continuously so that students can read quickly.

In addition, there is an increase in students' reading ability after the implementation of the book model of school library utilization, students have better reading skills, so students easily understand the books that have been read. There is an increase in students' ability to articulate empathy for the characters, know the types writing in the media and its purpose, understand the contents of the reading, retell the contents of the story with its language and express opinions on the story, and students are able to write responses to the storyline. A relatively small increase occurs in the ability to separate facts and fiction and listening skills.

Statistically, reading interest and reading ability of students before and after the implementation of the school library utilization model with paired sample t-test technique cab be tested, which shows the model of the use of school libraries can significantly increase students' reading interest. In detail, a significant increase in reading interest occurred, and most students became more and more amused to read books in the library (item.1), with the largest increase in scores of 0.60 . Furthermore, there are two items whose increase is not significant, namely item 2 (Desire to read the book ordered by the teacher) and item 6 (Like reading books in the library helping to do the test).

The paired sample t-test on students' reading ability also showed that the school library utilization model was able to significantly improve students' reading skills. In detail, a significant increase in reading ability occurs, most students are able to read better with understanding (item 2), with the largest increase in scores, which is 0.43 . Furthermore, there are two items whose increase is not significant, namely item 1 (speed reading ability) and item 4 (summarising ability).

The model of using the school library is also able to significantly improve students' reading skills. In detail, a significant increase in reading ability occurs in most students are more likely able to articulate empathy for the 
character of the story (item 1), and better understand the type of writing in the media and its purpose (item 4). Furthermore, there are four items whose increase is not significant, namely item 2 (separating facts and fiction), item 3 (presenting the story effectively), item 5 (listening ability to understand the contents of the reading) and item 6 (ability to understand the contents of the reading).

Furthermore, the results of student RTL level measurements after implementation showed that out of a total of 872 students, there were only 27 students or only $3.1 \%$ of students who had RTL levels were still below the minimum standard. Far down compared to the pre-test, there were $40.1 \%$ of students who had RTL levels below the minimum standard.

When viewed from the RTL that matches the level, before implementation (pre) RTL according to the level is 515 students or $59.06 \%$, and increases to 845 students or 96.9\% after the implementation (post). RTL, according to the level of each class can be seen in Figure 1 below:

\section{RTL according to level}

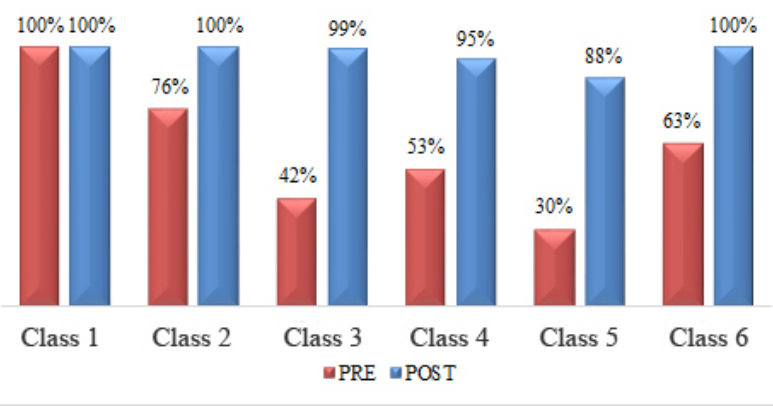

Figure 1. RTL according to level (Pre-Post)

Figure 1 shows, in general, there is an increase in the percentage of students who have RTL values according to the level. During the initial conditions, generally the class that had RTL students below the level was grade 3 and above, and after the implementation of the RTL students had increased by almost $100 \%$, that is, almost all students had RTL levels that matched the level.

The implementation of the school library utilization model in this study is effective because it is supported by a clear monthly work program. The work program consists of several activities consisting of service programs, administrative programs, book programs, and competition activities. The monthly work program and weekly scheduling are very important aspects in the process of implementing the school libraries utilization model, programs and schedules that determine the success of school library visit rate to increase students' interest and reading ability.

The work programs consist of the compulsory reading curriculum, summarising the contents of the book, library friends, bitter telling stories, speed reading, biotech summarising, singing and dancing, and competition activities. These programs are quite effective, because they combine reading, writing, and learning. Frankel [30] in his research entitled Integrating Reading, Writing, and Learning in Intervention Settings, explained that the integration of reading, writing, and learning in learning services was able to overcome complexity and strongly support learning for students.

The results of this study also show that reading programs with understanding can increase students' reading interest; high reading interest will have an impact on students' reading skills. Antonious [31] explains the strong association between reading comprehension, reading interest and reading efficacy, which shows that reading interest is positively influenced by students' reading comprehension and a structured and positive climate, to improve students' reading skills.

Based on the results of the discussion on the model of the use of school libraries in increasing students' reading interest, it can be seen that there are internal and external factors that also play a role in increasing students' reading interest. This is corroborated by the theory of Harris and Sipay [32]which states that factors affecting interest in reading can be divided into two, namely internal and external factors. Internal factors, also called personal factors, are factors that exist in students for example intelligence, reading ability, psychological attitudes and needs, while external factors, also called institutional factors, are factors outside of themselves, such as the availability of the number of reading books, parents' socioeconomic status, the influence of parents, teachers and peers.

Based on the theory that can be elaborated, internal factors of students are factors that come from themselves. Students read because they get benefits and pleasure/pleasure. Through reading, students who like reading activities gain satisfaction and gain increasing insight. If the students' internal factors towards interest and reading needs are high, then the real interest in reading can be easily developed. However, the role model from those who influence the students, such as parents, teachers, friends, and others, is needed to support students' reading interest.

Not only internal factors, but support from the surrounding environment also affects students' reading interest. From the researchers' observations, it was found that the discussion groups that analyze the book had not been done much even before. Moreover, from the existing reading group, on average, they only discuss educational books and lessons, some discuss humanitarian reading and light reading such as novels. In addition to the existence of book discussion groups, other things that are influential outside are cheap bazaar events. This activity supports students' reading activities because according to the results of the discussion, a cheap bazaar event is used by parents to buy books according to the needs of their children. This is in line with the information that most people like to read books that they bought by themselves and borrow from the library or friends. 
Technology can also support the reading hobby of students. The existence of online books can also increase students' interest and reading ability because this book can be downloaded free of charge and is relatively inexpensive when compared to conventional books, which have to incur greater costs. However, from the results of the study, it was found that students never use the e-books, it is because of students' lack of knowledge about how to download the e-book.

The use of technology also enables video learning services that are also effective; this was proven by [14] that videos could help teachers in the learning and teaching process so that instruction can be carried out more responsively and quickly. The use of video technology can also be implemented in libraries through programs to increase visual reading interest.

Increasing interest in reading is also related to motivation; among several things that motivate students to read, the biggest motivator is themselves. The second thing that affects is family factors. The existence of the School Library itself was still not optimally utilized by students. It can be seen from the visit data that is still low. The reason why students have never used the School Library is that they have never been to the library. Another reason is that they do not know the procedure for borrowing books. This is a fact that is quite astonishing to be used as an evaluation material for the School Library.

It is important for teachers to always provide motivation for each student through teacher involvement. Teachers who are heavily involved in student activities can increase the motivation and willingness of students to continue learning, because without motivation, concepts or models of school library utilization and the strategies carried out the results will be less optimal, as confirmed by [12] that improving learning skills for children is not enough through concept and strategy, but must be supported by motivation and social interaction. The involvement of teachers in the program to increase students' interest and reading ability show that there is a social interaction that can increase students' motivation to read.

Finally, the development of reading models is also an important point in increasing students' interest and reading ability. As is known, reading is the behavior of students to use books, but not many students are amused to read. The efforts made by the School Library for six months in this research have been very remarkable compared to other schools in Surabaya. However, even better, if you look at the results of research in reading interest, it turns out that the interest and reading ability of students at Bubutan IV Surabaya Elementary School can still be improved, with the hope that the work program that has been designed can be carried out continuously. The core of this work program is to conduct a massive campaign and be supported by several systems, such as instructions that bind to stakeholders in the internal and external schools and provide adequate infrastructure. Then, to develop a reading interest for students does require a planned effort, involving many parties and of course, the funds that have been planned from the beginning (budgeted). Reading interest will become a culture of students at school and outside of school when efforts are taken seriously and become an increasing public invitation [33], [34].

To become a passive activity, a strategy is needed, by adopting Natadjumena [35], namely by power strategy, persuasive strategy, and normative-reeducative strategy. The power strategy is carried out by disseminating the library utilization model to the Surabaya City Government, through the Education Office and the Library Agency, so that it becomes a regional regulation that must be implemented by all schools at the elementary level. Persuasive strategy is done by utilizing mass media and social media massively, which aims to shape public opinion and the public's view of the importance of reading. Furthermore, the normative-re-educative strategy is carried out by efforts to re-educate to install and replace the community's paradigm of thinking about reading.

\section{Conclusions}

Based on the analysis and discussion of the results of the research, the research conclusions are: (1) The initial conditions for the utilization of the Bubutan IV Surabaya Elementary School school library indicate that there are still some indicators that are still not in line with the standards. The results of the preliminary study on the initial conditions of library utilization also showed that students' reading interest was still lacking, students' reading ability was still lacking, especially reading ability was still not accompanied by a good understanding of the books that were read and understanding difficulty of the books that have been read.; (2) The library utilization model was developed through several stages, in which the previous draft was originally prepared to adjust SNI No. 7329 of 2009 concerning School Libraries and 6S programs (human resources, structures, systems, facilities and infrastructure, strategies, and synergies) [26]. Furthermore, the implementation was carried out for three months with a clear monthly work program and weekly scheduling because the success is determined by the utilization of the school library. After implementation, further evaluation is carried out whether the application of the school library utilization model book can increase reading interest and reading ability of students, and also increase the level of RTL of students according to the level at least every grade level.; (3) The model of school library utilization that has been designed, is very effective for increasing students' interest and reading ability. Reading interest and students' reading ability after implementation showed a good average score. The results of student, RTL level measurements, also showed that out 
of a total of 872 students, there were only 27 students or only $3.1 \%$ of students whose RTL level was still below the minimum standard. Far down compared to the initial investigation, there were $40.1 \%$ of students whose RTL level was still below the minimum standard. Also, the model of using the school library can significantly increase students' reading interest and reading ability.

\subsection{Suggestion}

Based on the conclusions of the study, the researcher gave several suggestions relating to the model of the use of the school library, namely: (1) The size of the book area within the school library must be considered, which is around $45 \%$ of the total library space. This is crucial in ensuring books collection arrangements can be done systematically and then the book browsing process and its utilization can be easier; (2) Planning of the School Library budget is more focused on adding a collection of up-to-date books, educational books and best-seller books so as not to be left behind from books in bookstores, and to increase the collection of magazines in the reading room. Convenience for visitors also needs to be planned in budgeting, especially the addition of facilities in the reading room to make it more comfortable. Also, librarians who are truly competent and understand the characteristics of people's reading interest are needed so that the books that are held are truly appropriate and useful.; (3) The use of school libraries must also be supported by clear work programs, both monthly programs and weekly scheduling, because it is a very important aspect in the process of implementing the model of school library utilization, programs and clear schedules that determine the success of school library use so that it can increase students' reading interest and reading ability.; (4) The teacher must always motivate each student through teacher involvement. Improving reading skills for students must be supported by teachers' motivation and social interaction. The involvement of teachers in the program to increase students' interest and reading ability shows that there is a social interaction that can increase students' motivation and interest in reading; (5) School libraries must also utilize information technology which is also supported by visual technology that can be implemented in libraries through programs to increase reading interest.

Based on the conclusions of the study, the researchers also gave some suggestions related to the dissemination of the model of the use of school libraries, namely: (1) The reading interest of students at Bubutan IV Surabaya Elementary School reflects that public interest in reading, especially those in the city of Surabaya, must start from the young children age; basically, the interest in reading is already inside, so it should be a concern for every Stakeholders (Schools, Universities, Education Offices, and City Governments) to appreciate it through collaboration with publishers and private companies through Corporate Social Responsibility (CSR) programs to routinely hold cheap book events and events related to books such as making stories and reading competitions with compensation or prizes in the form of books for free.; (2) The school library manager in the city of Surabaya can be bridged by the Office of Education to provide Literature Training in collaboration with the Archives and Library Agency. This is done to improve the competence of librarians so as to be able to instill early reading skills to students.; (3) To enhance the role of the School Library that supports for improving the nation's intelligence through developing interest in reading from an early age, it needs a comprehensive policy together with the Surabaya City Education Office and the Surabaya City Archives and Library Agency so that there are synergic, comprehensive and sustainable programs. The hope is that activities can be carried out in a structured, massive, systematic, and sustainable manner.

While the suggestions for further research are to conduct further studies of the school library utilization model that has been developed in this study, with the application of middle and upper-level schools, by making several modifications to the characteristics of these levels. Due to the target of basic level student reading skills, middle and upper have differences, the approach is also different.

\section{Acknowledgements}

We are very grateful to experts for their appropriate and constructive suggestions to improve this paper.

\section{REFERENCES}

[1] Depdiknas, Undang-Undang Republik Indonesia Nomor 20 tahun 2003 tentang Sistem Pendidikan Nasional. 2003.

[2] K. Raymona and B. R. M. Mitchell, "The effects of academic optimism on elementary reading achievement,” J. Educ. Adm., vol. 50, no. 6, pp. 773 - 787, 2012.

[3] "E-Reading theory, In Theoretical Models of Learning and Literacy Development,” pp. 245-268, 2014.

[4] G. J. Whitehurst and C. J. Lonigan, "Child development and emergent literacy,” Child Dev. J., vol. 69, no. 3, pp. 848872, 1998.

[5] D. Weigel and S. Martin, Literacy and Language Development. Nevada: University of Nevada Cooperative Extention and Agricultural Experiment Station, 2010.

[6] Depdiknas, Undang-Undang Republik Indonesia Nomor 43 Tahun 2007 tentang Perpustakaan. 2007.

[7] Depdiknas, Kajian Kebijakan Kurikulum Mata Pelajaran Matematika. Jakarta: Balitbang Depdiknas, 2007. 
[8] A. Delice and M. Kertil, "Service Mathematics Teachers in a Modelling,” Int. J. Sci. Math. Educ., vol. 2013, no. February 2012, pp. 631-657, 2013.

[9] O. Hamalik, Teknik Pengukuran dan Evaluasi Pendidikan. Bandung: Mandar Maju, 1989.

[10] V. Purcell-Gates, "Emergent literacy is emerging knowledge of written, not oral, language,” J. New Dir. Child Adolesc. Dev., vol. 92, no. 1, pp. 7-22, 2001.

[11] S. C. E., "What counts as literacy in early childhood?” in McCartney M, Phillips D (eds) Blackwell Handbook of Early Childhood Development, 2008.

[12] W. A. Mason-Singh, A. N. Ho, and J. T. Guthrie, "Intervening to Improve Children's Reading Motivation and Comprehension: Concept-Oriented Reading Instruction,” in Motivational Interventions, 2014, pp. 3770.

[13] N. S. A. Karim and A. Hasan, "Reading habits and attitude in the digital age: Analysis of gender and academic program differences in Malaysia,” Electron. Libr., vol. 25, no. 3, pp. 285 - 298, 2006.

[14] Rosaen, "The Potential of Video to Help Literacy Pre-Service Teachers Learn to Teach for Social Justice and Develop Culturally Responsive Instruction,” in Video Reflection in Literacy Teacher Education and Development: Lessons from Research and Practice, online Emeral Insight, 2015, pp. 3-19.

[15] Sugiyono, Metode Penelitian Kuantitatif, kualitatif dan R \& D. Bandung: Alfabeta, 2013.

[16] M. Kuncoro, Metode riset untuk bisnis dan ekonomi. Jakarta: Erlbaum, 2009.

[17] L. J. Moleong, Metodologi penelitian kualitatif. Bandung: PT. Remaja Rosda Karya, 2002.

[18] H. Freudental, Didactical Phenomenology of Mathematical Structures. New York, London: Kluwer Academic Publishers, 1983.

[19] A. Koesnandar, Media Pembelajaran. Jakarta: Pustekkom, 2006.

[20] Sulistyo and Basuki, Penghantar ilmu perpustakaan. Jakarta: Gramedia Widiasarana Indonesia, 1993.

[21] L. Outhred and M. Mitchelmore, "Students' Structuring of Rectangular Arrays,” in Proceedings of the 28th Conference of the International Group for the Psychology of Mathematics Education, 2004, vol. 3, pp. 465-472.

[22] Subandijah, Pengembangan dan Inovasi Kurikulum. Jakarta: Raja Grafindo Persada, 1993.

[23] B. Warsito, Teknologi Pembelajaran: Landasan dan Aplikasinya. Jakarta: Rineka Cipta, 2008.

[24] Mudhoffir, Prospek Pengelolaan Pusat Sumber Belajar. Bandung: Remadja Rosdakarya, 1986.

[25] Widayati, Transformasi Surabaya Sebagai Kota Literasi. Surabaya: Dinas Perpustakaan dan Kearsipan Kota Surabaya, 2013.

[26] Depdiknas, Standar Nasional Indonesia (SNI) Nomor 7329 tahun 2009 tentang Standar Perpustakaan Sekolah. 2009.
[27] A. Muhtadi, Manajemen Sumber Belajar. Yogyakarta: UNY Press, 2006.

[28] R. K. Yin, Studi kasus (desain dan metode). Jakarta: Grafindo, 2009.

[29] P. M. Yusuf and Suhendar, Pedoman penyelenggaraan perpustakaan sekolah. Jakarta: Kencana, 2007.

[30] E. L. Frankel and P. D. P. Jaeger, “Embracing Complexity: Integrating Reading, Writing, and Learning in Intervention Settings," in School-Based Interventions for Struggling Readers, 2015, pp. 3-20.

[31] G. D. S. Antoniou, "Prediction of reading comprehension, reading interest and reading efficacy from teaching styles and classroom climate: A multilevel random coefficient modeling analysis for students with learning disabilities," no. In Personnel Preparation, pp. 223-251, 2015.

[32] A. J. Harris and E. R. Sipay, How to Increase Reading Ability: A Guide to Development and Remedial Methods. New York: Longman Publisher, 2004.

[33] D. F. Bjorklund, Children’s thinking, cognitive development and individual deferences. Belmont: Thomson Learning, 2005.

[34] C. Juel, "Learning to read and write: a longitudinal study of children from first through fourth grade,” J. Educ. Psychol., vol. 80, no. 4, pp. 437-447, 2000.

[35] N. S. Sutarno, Perpustakaan dan masyarakat. Jakarta: CV. Sagung Seto, 2006. 